\title{
Legal Aspects on Financial Technology (Fintech) Peer to Peer (P2P) Lending that Declared Illegal by Otoritas Jasa Keuangan (OJK)
}

\author{
Harry Budi Artono \\ Krisnadwipayana University, Indonesia \\ \{kebhot66@gmail.com\}
}

\begin{abstract}
Fintech P2P Lending is a financial service that utilizes digital technology to bring together parties who need loans and parties who are willing to provide loans digitally. The presence of Fintech P2P Lending allows consumers to borrow money digitally with easy terms and a fast process. But in reality, not all Fintech P2P Lending is legal due to the rise of Illegal Fintech P2P Lending Companies that can potentially harm consumers because they often violate the privacy rights of consumers when they are about to collect online loan debts that are due by threatening and intimidating that they will spread consumer personal data on social media, even though based on Article 39 POJK No. 77/POJK.01/2016 that business actors are prohibited in any way, providing data and/or information regarding its consumers to third parties. The research method in this study is juridical-normative. The results indicated that Fintech P2P Lending business actors who were proven to have committed a criminal act in the form of distributing consumer personal data could be subject to criminal penalties under Article 32 jo. Article 48 of Law No. 19 of 2016 concerning Amendments of Law No. 11 of 2008 concerning Information and Electronic Transactions (ITE).
\end{abstract}

Keywords: Fintech P2P Lending; Illegal; Consumer Legal Protection; Legal Liability

\section{Introduction}

The growth and health of a country's economy in a sustainable manner is strongly influenced by the financial system in that country which functions as a facilitator for domestic and international trade, where stability and development of the financial system are very important so that people believe that Indonesia's financial system is safe, stable and can meet the needs of service users finance [1].

The rapid development of technology is due to the acceleration of the flow of information and a very wide coverage area and without encouraging the development of the digital financial industry with the existence of Financial Technology (Fintech). The term Fintech has become familiar in the Indonesian business world in recent years. The term Fintech is an abbreviation of Financial Technology, when translated into Indonesian it meana teknologi 
finansial. Article 1 point 1 of Bank Indonesia Regulation Number 19/12 /PBI/2017 concerning the Implementation of Financial Technology, that financial technology is defined as the use of technology in the financial system that produces new products, services, technology and /or business models and can have an impact on monetary stability, financial system stability, and /or efficiency, smoothness, security and reliability of the payment system.

In general, the Fintech that has developed in Indonesia can be divided into several groups, namely Payment Channel/System, Digital Banking, Online / Digital Insurance Fintech P2P Lending, and Crowdfunding. OJK regulation and supervision of the Fintech business is regulated in POJK No. 13/POJK.02/2018 concerning Digital Financial Innovation in the Financial Services Sector, which aims to support the development of responsible Digital Financial Innovations, support effective monitoring of Digital Financial Innovations, and encourage synergies in the digital financial services ecosystem as stipulated in Article 2 paragraphs (1) and (2) POJK No. 13/POJK.02/2018 concerning Digital Financial Innovation in the Financial Services Sector concerning the objectives of Digital Financial Innovation. The scope of the Fintech business in this POJK is divided into 8 (eight) types as regulated in Article 3 POJK No. 13/POJK.02/2018 concerning Digital Financial Innovation in the Financial Services Sector concerning the objectives of Digital Financial Innovation, namely:

a. Transaction settlement, in practice, transaction settlement is also known as settlement, such as those related to investment settlement,

b. Capital raising, such as equity crowfunding, virtual exchange and smart contracts, as well as alternative due diligence.

c. Investment management, including advance algorithm, cloud computing, sharing capabilities, open source information technology, automated advice and management, social trading, and retail algorithmic trading.

d. Investment management, including advanced algorithm, cloud computing, sharing capabilities, open source information technology, automated advice and management, social trading, and retail algorithmic trading.

e. Insurance, including sharing economy, autonomous vehicle, digital distribution and security and hedge funds.

f. Market support, including artificial intelligence / machine learning, machine readble news, social sentiment, big data, market information platforms and automated data collection and analysis.

g. Other digital financial supporters, including social / eco crowdfunding, Islamic digital financing, ewaqf, e-zakat, robo advise and credit scoring.

h. Other financial service activities, including trading invoices, vouchers, tokens, and blockchain application-based products.

One type of Fintech discussed in this study is Fintech P2P Lending, which is a financial service that utilizes digital technology to bring together parties who need loans and parties who are willing to provide loans digitally. Information technology plays an important role in the existence of Fintech, which is based on Article 1 number 5 POJK Number 77/POJK.01/2016 concerning Information Technology-Based Borrowing and Lending Services, that information technology is a technique for collecting, preparing, storing, processing, announcing, analyzing, and/or disseminating information in the field of financial services. The Fintech mechanism is based on Article 1 number 6, number 7, POJK number 77/POJK.01/2016 concerning Information Technology-Based Lending and Borrowing Services, that the system of Fintech Administrators will bring together the borrower and the party that provides the loan, so that Fintech-based Fintech services P2P Lending is a marketplace for lending and borrowing money online. 
The legal basis regarding the implementation of financial technology in Indonesia is regulated in Bank Indonesia Regulation Number 19/12/PBI/2017 concerning the Implementation of Financial Technology, where based on this regulation, the purpose of implementing financial technology is to encourage innovation in the financial sector by implementing consumer protection and risk management and prudence in order to maintain monetary stability, financial system stability, and an efficient, smooth, safe and reliable payment system.

The legal basis regarding on developments in technology and information systems that implemented to various innovations, especially those related to financial technology to meet various needs of society and can bring benefits to society. Another legal basis regarding financial technology is contained in the Regulation of the Financial Services Authority of the Republic of Indonesia Number 13/POJK.02/2018 concerning Digital Financial Innovation in the Financial Services Sector, where the development of financial innovation technology cannot be ignored and must be managed properly in order to provide benefits maximally for the benefit of society. Digital financial innovation also needs to be directed so that it can produce digital financial innovations that are responsible, safe, prioritize consumer protection and have well-managed risks. This is in line with the considerations of Bank Indonesia regulation Number 19/12/PBI/2017 concerning the implementation of Financial Technology.

The parties in this Fintech P2P Lending-based Fintech service consist of information technology-based lending and borrowing service providers, Lenders, Loan Recipients, and Otoritas Jasa Keuangan (OJK). Information technology-based lending and borrowing services are regulated in Article 1 number 6 POJK No. 77/POJK.01/2016 concerning Information Technology Based Lending and Borrowing Services. The operator in these provisions is an Indonesian legal entity that provides, manages, and operates information technology-based lending and borrowing services. The form of the organizing legal entity can be a limited liability company or a cooperative.

Fintech P2P Lending organizers must be legal entities and cannot be carried out by individuals or non-legal business activities such as Maatschap, Firma, or CV. Legal entities that can act as administrators of Fintech P2P Lending are only limited companies that have received approval from the Ministry of Law and Human Rights or Cooperatives. The requirements for administrators in the form of a limited liability company or cooperative are in accordance with the purpose of legal certainty for parties in the Fintech P2P Lending business where Fintech P2P Lending is a business activity that is profit-oriented and involves many parties.

The lender as stipulated in Article 1 number 8 POJK No.77/POJK.01/2016 concerning Information Technology-Based Lending and Borrowing Services is a person, legal entity, and / or business entity that has receivables due to information technology-based lending and borrowing service agreements. The lender can come from within and/or abroad. The lender consists of individual Indonesian citizens, individual foreign citizens, Indonesian/foreign legal entities, and/or international institutions. Individuals, both Indonesian citizens and foreigners, can act as lenders. In order for the Fintech P2P Lending business to provide legal certainty for the parties, it is necessary to implement a "Know Your Customer" system to avoid money laundering.

Loan recipients as stipulated in Article 1 number 7 POJK No.77/POJK.01/2016 concerning Information Technology-Based Lending and Borrowing Services are people and/or legal entities that have debts due to information technology-based lending and borrowing service agreements. Borrowers under the Peer to Peer Lending system must originate and live in the jurisdiction of the Republic of Indonesia. The recipient of the loan can be an individual 
Indonesian citizen or an Indonesian legal entity. Recipients of P2P Lending Fintech loans are not individual foreign citizens or foreign legal entities.

The Financial Services Authority is an independent institution, which has the function, task and authority of regulating, supervising, examining and investigating as referred to in Law No. 21 of 2011 concerning Otoritas Jasa Keuangan (OJK). OJK in the information technologybased lending and borrowing system acts as an approval provider for registration applications and licensing for system operation as well as the party that must receive periodic reports on the implementation of information technology-based lending and borrowing systems.

The presence of Fintech P2P Lending allows consumers to make money loans with easy terms and a fast process when compared to transacting directly through banks. But in reality not all Fintech P2P Lending is legal or licensed due to the rise of Illegal Fintech P2P Lending Companies. The Investment Alert Task Force (SWI), which has 13 (thirteen) ministries and agencies in its task of preventing public losses, continues to increase efforts to prosecute illegal Fintech Peer to Peer (P2P) Lending. From December to early January 2021, 133 (one hundred and thirty three) illegal Fintech Peer to Peer (P2P) Lending platforms were found in Appendix I of Press Release No. SP 01/SWI/1/2021, and if calculated from 2018 to January 2021, SWI has closed 3,056 illegal Fintech Peer to Peer (P2P) Lending.

The legal relationship between Fintech P2P Lending providers and OJK was born on the basis of the provisions of the laws and regulations in this case POJK No. 77/POJK.01/2016 concerning Information Technology Based Lending and Borrowing Services. Based on the POJK provisions, providers who intend to run the Fintech P2P Lending system must obtain permission from the OJK and after running the Fintech P2P Lending system must provide periodic reports to the OJK. Based on these provisions, it is clear that the implementation of Fintech P2P Lending must be licensed and under the supervision of the OJK. The legal relationship between Fintech P2P Lending providers and OJK is a legal relationship that was born from the provisions of laws and regulations not on the basis of an agreement. OJK as an independent institution established under the law has the capacity to supervise business activities carried out by OJK. This is aimed at realizing legal certainty and legal protection for the parties [2].

The impact of the rise of Illegal Fintech P2P Lending is detrimental to consumers using online loan services, one of which is by violating the privacy rights of customers as consumers when they are about to collect online loan debts that are due, such as intimidating and threatening to spread consumer personal data on social media, whereas based on Article 39 POJK Number 77/POJK.01/2016 concerning Information Technology-Based Borrowing and Lending Services, it is stated that Financial Service Business Actors are prohibited in any way, providing data and/or information about their Consumers to third parties. Therefore, consumer protection for users of online loan services is very important, especially in protecting consumer personal data. Every fintech company that will operate must have a permit first from the Financial Services Authority. This is regulated in Article 7 POJK No.77/POJK.01/2016 and Article 8 POJK No.77/POJK.01/2016 concerning Services Information Technology Based Lending and Borrowing.

The research method used in this research is juridical-normative legal research, with library material that includes primary legal materials, namely the 1945 Constitution, Law Number 11 of 2008 concerning Electronic Information and Transactions, Financial Services Authority Regulation Number 772016 concerning Information Technology-Based Lending and Borrowing and Financial Services Authority Regulation Number 13 of 2018 concerning Digital Financial Innovation in the Financial Services Sector, then secondary legal materials which include previous legal research, legal books, scientific journals, and other legal 
materials, then finally tertiary legal materials which include Indonesian dictionaries, and encyclopedias.

The problem formulations discussed in this study are as follows:

a. How is the consumer's legal protection against Illegal Peer To Peer (P2P) Lending Fintech users?'

b. What is the legal accountability for Illegal Peer To Peer (P2P) Lending business actors?

\section{Result and Discussion}

\subsection{Consumer Legal Protection Against Illegal Peer To Peer (P2P) Fintech Lending Users}

The term consumer comes from the word consumer (English-American), or consumer (Dutch), and the consumer is literally defined as "a person or company that buys certain goods or uses certain services 'or' something or someone who uses a stock or an amount goods"[3]. According to Nasution, consumer protection law is a part of consumer law which contains regulatory principles and also protects the interests of consumers. As for consumer law, it is defined as the whole principles or rules governing the relationship and problems between various parties with each other regarding consumer goods and or services, in social life [4].

Consumer protection in the financial services sector plays a very important role in financial system stability and economic growth in a country. Without adequate consumer protection, the public will not have confidence in the financial products and services offered by existing financial service institutions. In a 2012 World Bank study, it was stated that consumer protection in the financial services sector would increase efficiency, transparency, competition and access in the financial sector because it would reduce the occurrence of asymmetric information and inequality in positions between financial service institutions and consumers and the public. Consumer protection regulations will increase confidence in the financial sector because it will increase the transparency of financial products and services sold to the public, avoid unfair practices for consumers, and provide a standard for handling complaints for consumers who feel disadvantaged by business actors.

In order to encourage the realization of consumer protection in terms of matters, the OJK also issued regulations related to consumer protection in the financial services sector. According to the Financial Services Authority Regulation No. 1/POJK.07/2013 concerning Consumer Protection in the Financial Services Sector in Article 1 point 3 stipulates that consumer protection is the protection of consumers with the scope of behavior of Financial Service Business Actors. There are several principles, namely: transparency, fair treatment, reliability, confidentiality and security of consumer data/information, and handling complaints and resolving consumer disputes in a simple, fast, and affordable cost.

The issuance of the Financial Services Authority Regulation Number 1/POJK.07/2013 concerning Consumer Protection in the Financial Services Sector is a form of protection provided by OJK. The form of protection regulated Number 1/POJK.07/2013 concerning Consumer Protection in the Financial Services Sector is in the form of preventive and repressive protection. The form of preventive protection is carried out in the form of financial literacy programs and loss prevention programs, while the form of repressive protection is carried out in the form of dispute resolution, termination of activities or other actions, and legal defense to protect consumers [5]. 
The consumer protection aspect regulated in POJK Fintech P2P Lending regulates the basic principles of user protection as regulated in POJK No. 1/POJK/07/2013 concerning Consumer Protection in the Financial Services Sector, namely:

a. Providers are required to provide and / or deliver current information that is accurate, honest, clear and not misleading.

b. Providers are also required to use terms, phrases and / or Simple sentences in Indonesian that are easy to read and understood by the User in each Electronic Document.

c. Providers are required to have standard operating procedures serving Users contained in Electronic Documents.

d. The Operator is prohibited from providing data in any way and / or information about Users to third parties.

Efforts to strengthen consumer protection, especially in the financial services sector, prioritize 5 (five) principles, namely transparency, fair treatment, reliability, confidentiality and security of consumer data/information and complaint handling, as well as simple, fast, and affordable consumer dispute resolution [6].

Legal protection for consumers carried out by OJK is in the form of measures to prevent consumer losses, service complaints to legal defense against consumers in the financial services sector. Consumer loss prevention measures are implemented by giving information and education related to the characteristics of the financial services sector. Other than that OJK can ask financial services institutions to stop their activities if it has the potential to harm consumers or society. Complaint services consumers implemented by preparing complaint tools and mechanisms consumer complaints that are disadvantaged by business actors in the financial services sector. Furthermore, OJK can also provide legal defense in the form of ordering certain actions for financial services institutions to resolve complaints consumers, and can file a lawsuit against business actors or other parties which is detrimental to consumers [7].

Consumers who borrow money on registered finance, the Service Authority Finance also issued an OJK circular letter, namely in SEOJK Number 2/SEOJK.07/2014 concerning Services and Resolution of Consumer Complaints at Financial Service Business Actors. In SE OJK Number 2/SEOJK.07/2014 concerning Service and Resolution of Consumer Complaints to Service Business Actors Finance contains procedures related to Financial Service Business Actors in service and settlement of consumer complaints, so that consumers can complain about the losses suffered.

In addition, in POJK No. 13/POJK.02/2018 concerning Digital Financial Innovation in the Financial Services Sector, that Fintech business operators are required to maintain the confidentiality, integrity and availability of personal data, transaction data and financial data that they manage from the time the data is obtained until the data is destroyed. The requirements for the use of user data and information include:

a. Obtain the consent of the user;

b. Convey limits on the use of data and information to users;

c. Submit any changes to the purpose of data utilization and information to users in the event of a change of purpose utilization of data and information; and

d. The confidentiality, security and integrity of the data and information are guaranteed.

The existence of OJK as a supervisory agency in the financial services sector, is expected to be able to protect consumers from Financial Service Business Actors who are considered to be detrimental to the interests of consumers, in this case Fintech consumers. OJK as an institution that has the authority to supervise business activities in the financial services sector, must able to protect consumers of financial services who place their funds and / or take 
advantage of services available in financial service institutions, especially Fintech consumers. This is as stipulated in Article 4 letter c Law No. 21 of 2011 concerning the Financial Services Authority which states that one of the objectives of establishing the OJK is to protect the interests of consumers and the public in the financial services sector. This protection is intended to provide a sense of security to consumers as users of financial services. Fintech consumers as users of financial services have the right to get protection for their personal data at the company Fintech which provided financial services to him.

\subsection{Legal Liability Against Illegal Peer to Peer (P2P) Lending Fintech Business Actors}

In the event that Fintech Business Actors in collecting debts that are due to P2P Lending Fintech Users commit digital persecution actions and misuse of personal data from customers, this action violates the Prevailing Laws. Based on Law Number 11 of 2008 concerning Electronic Information and Transactions as amended by Law Number 19 of 2016 concerning Amendments to Law Number 11 of 2008 concerning Electronic Information and Transactions, as well as Regulation of the Minister of Communication and Information No. 20/2016 on Personal Data Protection in Electronic Systems includes sanctions for those who violate them.

It is stated in Law Number 19 of 2016 concerning Amendments to Law Number 11 of 2008 concerning Electronic Information and Transactions in Article 26 Paragraph 1 that unless otherwise stipulated by laws and regulations, the use of any information via electronic media that concerns a person's personal data must be done with the consent of the person concerned. Meanwhile, based on the Minister of Communication and Information Regulation No. 20/2016 on Personal Data Protection in Electronic Systems, states that the protection of personal data includes protection against the collection, collection, processing, analysis, storage, appearance, announcement, transmission, dissemination and destruction of personal data.

In the Regulation of the Minister of Communication and Information of the Republic of Indonesia No. 20 of 2016 concerning Personal Data Protection in Electronic Systems, that electronic systems that can be used in the process of protecting personal data are certified electronic systems and have internal rules regarding personal data protection which must pay attention to aspects of the application of technology, human resources, methods, and the cost. In Article 26 of the Regulation of the Minister of Communication and Information Technology of the Republic of Indonesia No. 20 of 2016 concerning Personal Data Protection in Electronic Systems, it states that the owner of personal data has the right to the confidentiality of his data; has the right to file complaints in the context of resolving personal data disputes; has the right to have access to historical personal data; and has the right to request the destruction of certain personal data of hers in the electronic system.

Every electronic system operation is obliged to notify the Personal Data Owner in writing if there is a failure to protect the confidentiality of personal data. The information that must be submitted includes:

a. Reasons or causes for the failure to protect the confidentiality of personal data can be done electronically.

b. Must be ensured that it has been received by the owner of the personal data if the failure has potential harm to the person concerned.

c. Written notification is sent to the personal data owner no later than 14 (fourteen) days after the failure is found.

In addition to administrative sanctions, in accordance with Law Number 19 of 2016 concerning Amendments to Law Number 11 of 2008 concerning Electronic Information and 
Transactions, that if it is proven that there is a violation of the misuse of personal data by a third party and fulfills the criminal element of misusing personal data information and causing loss, then they can be punished with imprisonment of up to 12 years and / or a maximum fine of Rp. 12 billion, so that P2P lending business actors who are proven to have committed a criminal act in the form of distributing consumer personal data can be subject to punishment under Article 32 jo Article 48 of Law Number 19 of 2016 concerning Amendments to Law Number 11 of 2008 concerning Electronic Information and Transactions.

\section{Conclusion}

Based on the above analysis, the conclusions of this study can be described as follows:

a. Legal protection of consumers for Illegal Lending P2P Fintech users is regulated in several Laws and Regulations, namely POJK Number 1/POJK.07/2013 concerning Consumer Protection in the Financial Services Sector, where the legal protection in these regulations is in the form of protection preventive and repressive; in SE OJK Number 2/SEOJK.07/2014 concerning Service and Resolution of Consumer Complaints to Service Business Actors Finance contains procedures related to consumer complaining about losses suffered; and POJK No. 13/POJK.02/2018 concerning Digital Financial Innovation in the Financial Services Sector, which requires Fintech business operators to maintain the confidentiality of customer data.

b. Regarding the legal accountability for Illegal Peer To Peer (P2P) Lending business actors, that the actions of Fintech Business Actors who violate the Prevailing Laws may be subject to both administrative and criminal sanctions based on the Regulation of the Minister of Communication and Information of the Republic of Indonesia No. 20 of 2016 concerning Protection of Personal Data in Electronic Systems, and Article 32 jo. Article 48 of Law Number 19 of 2016 concerning Amendments to Law Number 11 of 2008 concerning Electronic Information and Transactions.

\section{References}

[1] Djoni S. Gazali, Rachmadi Usman: Hukum Perbankan, Sinar Grafika, Jakarta. pp. 41 (2016).

[2] Ratna Hartanto dan Juliyani Purnama Ramli, Jurnal Hukum IUS QUIA IUSTUM, "Hubungan Hukum Para Pihak dalam Peer to Peer Lending", No.2 Vol.25, Fakultas Hukum Universitas Islam Indonesia. pp. 325-336 (2018).

[3] Firman Tumantara E, Hukum Perlindungan Konsumen: Filosofi Perlindungan Konsumen dalam Perspektif Politik Hukum Negara Kesejahteraan, Setara Press, Malang. pp. viii (2016)

[4] Nasution Az, Konsumen dan Hukum: Tinajauan social, Ekonomi dan Hukum pada Perlindungan Konsumen Indonesia, Pustaka Sinar Harapan, Jakarta. pp. 72 (1995).

[5] Bahir Mukhammad dan M. Hudi Asrori, Kewenangan Otoritas Jasa Keuangan Terhadap Ganti Kerugian Nasabah Bank Yang Belum Dibayar Pihak Bank, Jurnal Privat Law, Vol. V, Bagian Keperdataan Fakultas Hukum Universitas Sebelas Maret, Surakarta. pp. 35 (2017). 
[6] Otoritas Jasa Keuangan, "Strategi Perlindungan Konsumen Keuangan Tahun 20132027”, Bidang Edukasi dan Perlindungan Konsumen Otoritas Jasa Keuangan Republik Indonesia. pp. 2-4 (2017).

[7] Agus Suwandono, "Implikasi Pemberlakuan Undang-Undang Otoritas Jasa Keuangan Terhadap Perlindungan Konsumen Jasa Keuangan Dikaitkan Undang-Undang Perlindungan Konsumen", Perspektif, Vol.21 No.1, Fakultas Hukum Universitas Padjadjaran. pp. 2-4 (2016). 